\title{
日本語教育実習におけるアクション・リサーチの役割
}

\section{Role of Action Research in Pre-service Education of Japanese as a Second Language}

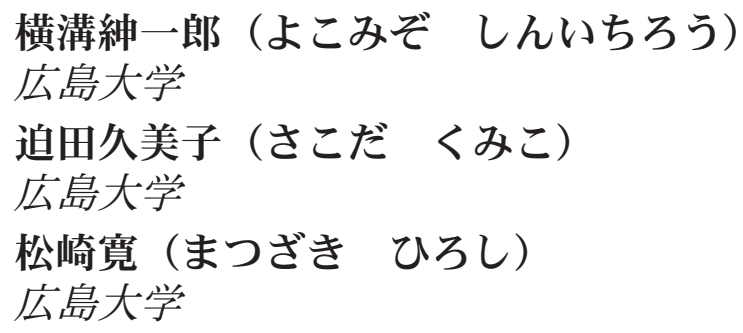

In the field of teaching Japanese as a second language, teacher education has recently received much attention as seen in the increasing number of presentations and articles (e.g., Ozaki et al., 2000; Nihongo Kyooin Yooseikatei Choosa Kenkyuu Iinkai, 2001; Yokomizo and Tohsaku, 2003). The increasing attention to this type of study derives from the paradigm shift from "teacher training" (in which one type of teaching is considered the uppermost model to master) to "teacher development" (in which each teacher seeks their own good teaching). In this new paradigm, "self-directed teachers" and "reflective practitioners" have been considered models of a good teacher since they constantly develop themselves as a teacher. Action research (hereafter, AR) has been paid much attention as a means to realize these models.

Like other fields of education, AR has been conducted in the field of teaching Japanese as a second language, too (Tsuda, 1998; Yokoi, 1999; Nakamura \& Yamada, 2000; Yokomizo, 2000; Mihara et al., 2001). However, its number is still rather limited and almost all of them have been conducted by in-service teachers. Sakoda (2000) is the only study which introduced AR to student-teachers

JALT Journal, Vol. 26, No. 2, November, 2004 
(i.e., pre service teachers), but the analysis of this attempt is merely based upon the observation of the teacher in charge of the course.

This particular study is a case study to clarify the role of AR when it is introduced into a practicum course of teaching Japanese as a second language. By qualitative analysis of the data gained from participants of the practicum course in 2001, 2002, and 2003 (3 teacher educators, 6 teaching assistants and 41 student teachers), this study attempted to investigate student-teachers' development throughout the course.

Student-teachers' development was observed in positive aspects, such as (1) positive learning attitudes, (2) co-development with other student-teachers, (3) realization of the importance of 'teacher as a researcher', (4) attention to learners, (5) realization of self-development in their selected AR topic, and so forth. At the same time, this study revealed several problems. The most serious problem was the "double burden" of teaching and conducting AR in the same course. As a concrete solution, Exploratory Teaching (Allwright, 1999), is suggested to those with limited teaching experience.

This particular research is merely a case study, and therefore, its results and discussions are likely to be valid only within the context of the study. It can be expected that different results will occur when AR is introduced in other contexts of a practicum course of teaching Japanese as a Second Language. Further studies are awaited in order to clarify possibilities and limitations of teaching practicum courses within the framework of teacher development.

本研究は、「アクション・リサーチ（以下、AR）」を導入した「教師成長型」日本語 教育実習を紹介し、参加した実習生の内省の分析を通して、実施に伴う問題点を考察する 事例研究である。2001、2002、2003年度の実習期間中に実習参加者から得た実習前のデー 夕と実習後のデー夕を質的に分析し、（1）積極的態度の養成、（2）共同成長、（3） 「研究者としての教師」の重要性の認識、（4）学習者への注意力、（5）各自選択したテ 一マ内での自身の成長の認識等の観点から、考察を行った。また、特に「実習生の実習 授業とARの二重負担感」という問題点を克服するために2003年度に実施した「探究的授 業」について紹介した。

\section{はじめに}



内の日本語学習者は英語学習者に比して数が少なく、かつ多様であ るため、日本語教育の教壇実習は、民間学校や公的機関、あるいは 海外の日本語学習機関と連携して行ったり、一時的に学習者を募集 して行ったりするなど、実施に困難が伴うことが多いが、近年では、実習に関 する研究発表や論文も増加し、日本語教師養成についての議論が盛んに行われ ている（尾崎他、2000; 日本語教員養成課程調査研究委員会、2001; 横溝 - 當 作、2003）。特に最近、実習生の変容についての研究が、様々なタイプの教育 実習の事例研究として進められている（小笠他、2000 ; 岡崎、2002a、2002b ; 小熊他、 2000 ; 白石他、 2000 ; 林・八田、2000）。本研究は、「アクション • リサーチ（以下、AR）」を日本語教育に導入した場合の実習生の反応や内省を 多様なデー夕に基づいて分析し、ARの教育実習への導入の意義と有効性につい て述べるものである。 


\section{先行研究調査}

\section{教師の自己成長をめぐる議論}

よりよい日本語教師を育成していく方法として、1980年代までは、教師と して必要だと思われる技術を指導者が訓練によってマスターさせ、教える能力 を伸ばしていこうとする「教師トレーニング」という考え方が主流を占めてい た。しかしながら、教師が教室の中で実際に直面する問題は多種多様であり、 トレーニングによって吅き込まれた一つの教え方を忠実に実行するだけでは対 応できない場合も少なくない。そこで、「教師の成長」という考えで、教師の 育成を図ろうとするようになった。岡崎・岡崎（1997）は、「教師の成長」を 次のように説明している。

教師養成や研修にあたって、これまで良いとされてきた教え方のモ デルを出発点としながらも、それを素材にくいつ、つまりどのよう な学習者のタイプやレベル、ニーズに対して、またどんな問題があ る場合に＞、〈なぜ、つまりどのような原則や理念に基づいて＞教 えるかということを、自分なりに考えていく姿勢を養い、それらを 実践し、その結果を観察し改善していくような成長を作りだしてい $<$ (岡崎・岡崎、1997:9-10)。

その結果、日本語教師には、自分が持っている「どう教えるか」について の考えを自分の教育現場の実際に応じて捉え直し、それを実践し、その結果 を観察し内省して、より良き授業を目指すことができる能力が要求されるよ うになった（横溝、2000a）。このような能力を持った教師のモデルとして挙 げられるのが、無意識に作り上げてきた自分の言語教育観やそれに基づいた 教授法やテクニックの問題点を、学習者との関わりの中で見直していく作業 を自らに課す「Self-directed Teacher（自己研修型教師）」（Nunan and Lamb、 1996 ; 岡崎・岡崎、1997訳）であり、自分や他の教師の教授過程を観察し振り 返る中で、教授・学習過程の重要な諸点を発見していく「Reflective Practitioner

（内省的実践家）」（Schön、1983；岡崎・岡崎、1997訳）である。

\section{教師成長型の実習}

「自己研修型教師」並びに「内省的実践家」の育成を目標とした日本語教育 実習としては、Wallace（1991）の「内省モデル」に基づいて実施された「教師 成長型実習」プロジェクト（岡崎、2002a、2002b）が挙げられる。同プロジェ クトは、教師成長型実習の中で「教師の意思決定」「授業評価」「日本語教育 観」等の観点から、実習生がどのような変容を見せたかについて分析している が、その中で、実習生の内省が実際にどのように変容していったのかをまとめ 分析したものとして、影山(2002)がある。影山は、教師成長型の実習の場合、 教師トレーニング型の実習と比較して、自分の教育実践を対象化し振り返ると いう内省行為に、以下の特徵があると報告している。

・内省に使用する材料が広範囲に渡ること(文献講読などによる先行研究か らの知見、授業のフィールドノーツ、学習者からのコメント、教案・教 材などの関連書類、実習生への質問紙調査など) 
・時間的広がりがあること(現在進行中の内省から将来への展望へとつなが ること)

・変容性があること(内省が統合されて変容していくこと)

\section{$A R$ と教育実習}

「自分の教室内外の問題及び関心事について、教師自身が理解を深め実 践を改善する目的で実施される、システマティックな調査研究」（横溝、 2000a:17）と定義されるARも、「内省モデル」と同様に、「自己研修型教師」 並びに「内省的実践家」の育成を目標とするものである。日本語教育分野にお けるこれまでのARの実践報告では、実践者はほとんどの場合、現職教師であ つた（津田、1998 ; 横井、1999 ; 中村・山田、2000 ; 横溝、2000b ; 三原他、 2001）。しかしながら、教育実習などの教師教育プログラムの中でもARは実 施可能であり、Johnson (1993)、Rossiter (1993)、Stephens and Reimer (1993)、 Markee (1996)、Thorne and Qiang (1996)等の、教育実習プログラムへのARの導入 に関する報告も数多くなされている。その中で、英語教育実習にARを導入した Moreira、Vieira and Marques (1999)は、ARの導入が「学習者中心の教え方の重要 性の認識」「教えることについての内省的態度の助長」につながったと報告し ている。

日本語教育の分野では、迫田(2000)が、大学院生対象の教育実習にARを導入 することの意義について、以下のように報告している。1

・ 教師養成から教師成長へ…「指導技術や知識を実地訓練により指導者が 教え示すこと」と考えられがちな教育実習にARを取り入れることで、

「実習生自身による自らの成長を促すこと」と捉えることができ、自己 研修型の教師を育てることができる。

・ 他実習生の協力…教室の参観者たちに深い内省のための質問紙調査を容 易に依頼できる。

・他実習生への影響…他実習生の様々なARを知ることで、新たな観点の広 がりが得られる。

・実践と研究に対する高い意識…「教師は教授活動に、研究者は研究に」 ではなく、現場での取り組みがそのまま研究となることを認識し、日々 努力する教師を目指すようになる。

迫田(2000)は一方で、以下の問題点も指摘している。

・実習回数による研究の制約…短期間の実習では、結果が出てもARによる ものか指導によるものかが曖昧。

・ 問題認識の甘さ…実習前にARのテーマを選定するのが困難。

・ 学習者の調査…学習者への授業以外の作業依頼は、実習先機関との交渉 が必要で困難。

・実習担当内容の制約…担当内容（文法導入か会話練習か等）をARのため に制御すると、様々な内容の授業が担当できない。 
・実習授業とリサーチの二重負担…担当する授業準備だけでも大変なの に、ARの質問紙作成などの作業負担が増える。

迫田（2000）の指摘は具体的で示唆に富むが、実習生のデー夕が調査者の観 察のみによるものであり、考察も調査者の推測の域を出ていない等の限界が存 在している。そこで本研究では、実習生によって書かれた実習前と実習後のデ 一夕に基づいて実習生の内省自体を分析し、日本語教育実習へのAR導入の意義 と有効性を明らかにする。

\section{調查方法}

2001、2002、2003年 7 月初旬から 8 月初旬までの公的教育機関における教 壇実習を前提とした実習授業期間（ 4 月〜8月）中に、教育実習生のデータ (1) (2)を収集した（2001年度14名、2002年度12名、2003年度15名）。

(1) 教育実習生が実習前に提出した「私の日本語教育哲学」（各自A4一枚）

(2) 教育実習生が実習後に提出した「教育実習を通じての学びと感想」（各 自A4一枚)

以下、この(1)と(2)のデータを比較し、担当教官 3 名とティーチング・アシス タント 2 名の観察を参照するかたちで考察を進める。データの分析には、得ら れたデー夕をつき合わせて生じた出来事を複数の視点から分析する「調査者の トライアンギュレーション」（Freeman、1998)2を採用した。AR導入は、表 1 の ような形で行った。導入手順等の日付以外の条件は2001年〜2003年とも変わら ない。

各実習生が選択したARのテーマは以下の通り。（）内は、後のデータに 付した実習生のイニシャルである。

\section{[2001年度]}

・ ティーチャートーク（KC、SY、SH）・教師のアクセント・イントネー ション（NE）・肯定的フィードバック（BJ）・否定的フィードバック (CK、 KM) ・ 否定的・肯定的フィードバック（KY）・指示の出し方 （KA、YY）・ロールプレイの後のフィードバック（SM）・教室活動の スムーズな流れの作り方（FY）・教師の表情（HS）・予測できない事態 への対応（時間配分を中心に）（HT）

\section{[2002年度]}

・ ティーチャートーク（KE）・発話矯正とティーチャートーク（HS）・誤

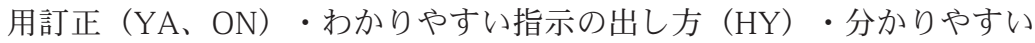
導入・説明の仕方 (AY) ・ 効果的な機械的ドリル (OR) ・ 学習者の理解 の確認と理解できていない時の教師の対処法（NK）・教室内インターア クション（MY）・発話の促し方（IA）・メリハリのある授業（KS）・ 予想外の出来事が起こったときの対処の仕方（OS）

\section{[2003年度]}

・ ティーチャートーク（DK、OT、YYa）・誤用訂正（AK、YYb、RS）・ 指示の出し方 $(\mathrm{HC}) \cdot$ 答えの引きだしかた $(\mathrm{TN}) \cdot$ 学習者同士のインタ 


\section{表1＼cjkstart実習授業の内容とARの進め方(日にちは2002年度のもの)}

\begin{tabular}{|c|c|c|}
\hline 日にち & 授業 & ARの進め方(斜体は、授業時間外の課題) \\
\hline 4月10日 & \begin{tabular}{|l|} 
オリエンテーション/教室 \\
活動の流れ/ARの説明
\end{tabular} & $\begin{array}{l}\text { ARについての説明/『日本語教師のためのアクション・リサー } \\
\text { チ』を読んでくる/ARノート購入/「私の日本語教育哲学」を } \\
\text { 書いてくる }\end{array}$ \\
\hline 4月17日 & 授業分析の方法1 & $\begin{array}{l}\text { ARのテーマを、『日本語教師のためのアクション・リサー } \\
\text { チ』に基づいて決めてくる }\end{array}$ \\
\hline 4月24日 & 授業分析の方法2 & 各自のARテーマの発表 \\
\hline 5月1日 & 休み & 休み \\
\hline 5月8日 & $\begin{array}{l}\text { 日本語教育機関 } \\
\text { 見学の打ち合わせ }\end{array}$ & $\begin{array}{l}\text { 日本語教育機関見学の打合せ(自分のARのテーマに関係あり } \\
\text { そうな授業をできるだけ選択)/自分のARのテーマに先先 } \\
\text { 行研究調査 }\end{array}$ \\
\hline 5月15日 & $\begin{array}{l}\text { 日本語教育機関見学 } \\
\text { (学外) }\end{array}$ & $\begin{array}{l}\text { 日本語教育機関見学(特に自分のARのテーマに注目して)/ } \\
\text { 自分のARのテーマに関する先行研究調査 } \\
\end{array}$ \\
\hline 5月23日 & $\begin{array}{l}\text { 日本語教育機関見学 } \\
\text { (学外) }\end{array}$ & $\begin{array}{l}\text { 日本語教育機関見学(特に自分のARのテーマに注目して)/ } \\
\text { 自分のARのテーマに関する先行研究調查 }\end{array}$ \\
\hline 5月30日 & $\begin{array}{l}\text { 日本語教育機関見学 } \\
\text { (学外) }\end{array}$ & $\begin{array}{l}\text { 日本語教育機関見学(特に自分のARのテーマに注目して)/ } \\
\text { 自分のARのテーマに関する先行研究調查 }\end{array}$ \\
\hline 6月5日 & \begin{tabular}{|l|} 
教材研究/ \\
教案作成の説明
\end{tabular} & $\begin{array}{l}\text { 見学で学んだことと先行研究調査で分かったことに基づい } \\
\text { て、自分なりの行動方略を考える }\end{array}$ \\
\hline 6月12日 & \begin{tabular}{|l|} 
教案の作り方(作成してき \\
たものを分析・検討)
\end{tabular} & $\begin{array}{l}\text { 見学で学んだことと先行研究調査で分かったことに基づい } \\
\text { て、自分なりの行動方略を考える }\end{array}$ \\
\hline 6月19日 & $\begin{array}{l}\text { 実技練習(マイクロ } \\
\text { ・ティーチング) } 1\end{array}$ & $\begin{array}{l}\text { 自分で立てた行動方略実施計画を実行し、その結果を観察 } \\
\text { し、成果を内省する。観察・内省デー夕は、授業者と観察者 } \\
\text { から得る。 }\end{array}$ \\
\hline 6月26日 & $\begin{array}{l}\text { 実技練習(マイクロ } \\
\text { ・ティーチング) } 2\end{array}$ & $\begin{array}{l}\text { 自分で立てた行動方略䒠施計画を実行し、その結果を観察 } \\
\text { し、成果を内省する。観察・内省デー夕は、授業者と観察者 } \\
\text { から得る。 }\end{array}$ \\
\hline 7月3日 & 実習授業1 & $\begin{array}{l}\text { 行動方略実施計画を実行し、その結果を観察し、成果を内省 } \\
\text { する。 }\end{array}$ \\
\hline 7月10日 & 実習授業2 & $\begin{array}{l}\text { 行動方略実施計画を実行し、その結果を観察し、成果を内省 } \\
\text { する。 }\end{array}$ \\
\hline 7月17日 & 実習授業3 & $\begin{array}{l}\text { 行動方略実施計画を実行し、その結果を観察し、成果を内省 } \\
\text { する。 }\end{array}$ \\
\hline 7月24日 & 実習授業4 & $\begin{array}{l}\text { 行動方略実施計画を実行し、その結果を観察し、成果を内省 } \\
\text { する。 }\end{array}$ \\
\hline 7月31日 & 実習授業5 & $\begin{array}{l}\text { 行動方略実施計画を実行し、その結果を観察し、成果を内省 } \\
\text { する。 }\end{array}$ \\
\hline 8月7日 & 実習授業6 & $\begin{array}{l}\text { 行動方略実施計画を実行し、その結果を観察し、成果を内省 } \\
\text { する。 }\end{array}$ \\
\hline 8月16日 & & 各自のAR報告書を書きあげて提出する(約4000字)。 \\
\hline 8月下旬 & \begin{tabular}{|l} 
実習授業の学習者の \\
スピーチを聞きに行く
\end{tabular} & $\begin{array}{l}\text { 訂正を受けたAR報告書を書き直し、最終的なものに仕上げ } \\
\text { る。 }\end{array}$ \\
\hline
\end{tabular}


ーアクション（AK、HH）・学習者のレベル差（GH）・メリハリのある 授業（AM）・教師の表情（NM）・教師の視線（KR）・学習項目の導入 と教材 (MY)

\section{調査結果}

以下、日本語教育実習へのAR導入によって観察された実習生の反応と内省の 分析およびそれぞれの根拠となるデー夕を示す。特に内容に深く関係する箇所 には下線を付す。 を示す。

（）内の実習生のイニシャルの後の数字は年度、前は実習前、後は実習後

\section{自己成長への積極的態度の養成}

「担当教官から指導技術や知識を教え示してもらおう」という実習生の受動 的態度が、「自らに働き掛け自らの成長を促すこと」という積極的態度に変化 する。実習生が実習開始時までに身につけている指導技術や知識は、個人差は あるものの、かなり限定されたものであることが多い。それ故、担当教官から の指導技術や知識の教示がされるのであるが、その教示に実習生が一方的に頼 っていては、「自己研修型教師」の育成にはつながらない。教師に頼るのでな く、自らが問題を見つけ、解決方法を学ぶことが重要である。

実習生KS2002の教育実習前の内省では、学部時代の教師のアドバイスを基に した考えが述べられており、教師からの意見の影響が強いことが窥える。

・さらに練習の流れを組み立てる際に気をつけているのが「らせん状」に なっているかどうかということである。これも先生のアドバイスである が、らせん状になるように、一つの練習から次の練習に移るときにそれ は前の段階を踏まえてそれに一つだけ新しい練習が続けば、余計な説明 に時間を取られずに、次の練習に進むことができるということである （実習生KS2002前）。

しかし、ARを取り入れた教育実習後の内省では、以下のように自分で解決す る方法を学んだことを述べており、自己成長への態度が養成されたことが推測 できる。

・5年前に受けた教育実習では、ただただ教壇にきちんと立って教えることに必 死だった。その中で学んだことは、普段無意識に使っていた日本語を「外から見 る」ということや、日本語を教える面白さと難しさであった。しかしこの害習で は、「どう教えるか」その工夫や改善を自分でしていく方法を学んだ（実習生 KS2002後）。

実習生KA2001の実習後の内省にも、受動的態度から積極的態度への変化が見 られる。

・最初は、単に教授経験がなかったため「授業をしてみたい」「授業のしかたを勉強 したい」という単純な動機で受講したのだが、思った以上に大変でなおかつ勉強に なるものだったと思う。今後、どのような場で日本語を教えていくのかわからない が、失敗を恐れず、常に自分の授業をより良いものにするという意欲を持ち続けた いと思う（実習生KA2001後）。

また、以下のデータでは、ARの実施が自己成長の必要性と重要性の認識につ ながったということが示されている。 
・ ビデオを撮ったり、観察者に意見を言ってもらうことによって、自分の授業を客観 的に見ることができた。自分を成長させて、学習者にとつてより良い授業にするた めにARという方法をとるのは、本当に重要だと思う（実習生YY2001後）。

・（授業で生じた）課題を解決しつつ、新しい課題が次々と襲ってくるのだろうなと 思っている。しかし、そうでなければ、教師として私は成長できないだろう。この 先、日本語教師として教壇に立つ中で、この実習で自分が感じたことを忘れずに常 に成長する教師でありたいと思う（実習生YY2003後）。

\section{共同成長の実現}

ARのデータをお互いに提供し合い、お互いの気づきを共有し合うため、実習 生の共同成長が実現する。もともと教育実習では共同作業が行なわれることが 多いが、ARの実施は共同作業の機会を増やすことにつながり、その結果、実習 生の共同成長も大きなものになる。

・自分自身を内省し、次に生かせるようにするということで本当にいい経験になっ た。ただ単に実習をするより、ARもする方が、自己を見つめる機会が増えると感 じたし、また周りの人からも自分が気になっているテーマについての意見が得られ るので、自分自身の成長にも繋がると感じた。これからも自分を見つめ、改善した い点を取り上げ、リサーチを行いたいと思っている（実習生NE2001後）。

・ 今回のARで、一番よかったと思うことは、たくさんの人に自分を観察してもらえ たことだ。…今回のように一回の授業を十数名の人に見てもらい、コメントをいた だける機会はなかなかないのではないかと思う。実習で自分の授業をたくさんの人 に見てもらう前は、䎵ずかしくて見てもらいたくないと思っていたが、今、実習を 終えて自分以外の視点の必要性を強く感じた。自分で考え、実行することも大切。 そして、それとともに、他者からの指摘や助言を受けることも、自分自身が成長す る上でとても大切なことであると実感した（実習生IA2002後）。

・実習はARを行なう環境としては最高である。自分だけでなく、他の人からも多く の意見をもらえるからである（実習生OS2002後）。

上記の実習生OS2002の実習前の内省には「教師は〜べきである」「必要であ る」のような気負いを感じさせる記述が多かった。

・ 交流が円滑にできるような授業にするために教師はどのようにするべきか。‥国 際交流を円滑にするためには、言葉が必要である。言葉を学ぶためには教師と学習 者、学習者同士の信頼関係が必要である。また、授業の中で学習者が言語学習に充 実感を持ち、楽しいと感じる必要がある（実習生OS2002前）。

しかし、ARを実施し、未熟な教師としての自分に気づき、それを認め、他の 実習生と共に学ぶことによって、肩の力を抜いて教師のあり方を考えることが できるようになったものと考えられる。

\section{「研究者としての教師」の基礎の構築}

現場での取り組みがそのまま研究となりえることを理解し、研究に対する 意識を失わず日々努力する教師を目指すことの重要性を認識する。「教師は教 え、研究者は研究する」といった実践と研究の乘離は今に始まったことではな いが、教師の成長という枠組みの中では、教育現場での現職教師による研究が 必要不可欠である（横溝、2000）。ARを実習時に実施することによって、「研 究者としての教師」の基礎を構築することが可能になる。 
・確かに、自分の授業を観察して反省をすることに最初は抵抗を覚えた。しかし、現 実から目を背けていては決してよい教師にはなれないだろう。私自身も今回ARを することによって、テーマ以外の問題点も発見することができた。これからも、「 学習者にとって最善の授業」を心掛けて、研究・改善していきたいと思う（実習生 SM2001後）。

・今回実践してみて、「リサーチ」だと大げさに聞こえるが毎日の授業で行える範囲 のことであり、一方「リサーチ」という形にすることで「なんとなく変えてみる」 のではなく、その結果を振り返りまとめをして次につなげるということは大事であ ると思った。教室という環境は他の人からあまり見られたり評価されたりしにくい ものである。それが固定化してしまわないように、毎日の授業がより良いものにな つていくようにしていく一つの方法として、このARを実践したことは、この実習 の最大の「学び」であった（実習生KS2002後）。

\section{学習者への注意力の養成}

学習者の反応に注目するようになり、学習者への注意力が養われる。実習生 はとかく教案の内容に注意が注がれ、学習者へ注意がいかないという問題点が 指摘されていたが（堀口、1992）、ARの行動(action)の成果を知るためには、そ れが学習者にどう受けとめられたのか、それによって学習者に何が生じたのか を注意深く観察する必要が出てくる。その結果、「学習者一人一人の学びに注 目する」という教師の基本姿勢を育成することができる。

教育実習後の内省では、以下のように、学習者に注目するようになった自分 に対する肯定的な記述が見られる。

・（細かく準備したことが）効果的だったということは、人からの意見だけでなく実 際授業で学生を見てわかった。ほんの数秒の違いかもしれないが理解されやすさが 違うことを学生の反応で実感した。嬉しかった（実習生KS2002後）。

・もう少し学習者のみなさんと過ごせたらもつと話もはずんだのではないかと思い ます。これまで日本語がわからない人に直接法で教えるなんてできるのだろうかと 信じられなかったのですが、顔の表情やジェスチャー、目や耳から情報を与えるこ とでこんなにも伝えることができるのだととても感動しました。授業が終わった後 に、話しかけてくれた時はとても嬉しかったです（実習生NK2002後）。

・私は結局毎週足を運んだのだが、休み時間に彼らと話すのが楽しみでしかたな かった。教案や教材を作るときにも、「○○さんはどんな反応するかな?」とわ くわくしていた。教えるって大変だけど、楽しいものなのだと思った（実習生 TN2003後)。

上記実習生の実習前の内省では、以下のように、良い授業の条件は「教案の 内容」と「教師の性格」によって決まるという記述が多く、ここには学習者と の関わりに関する記述は、ほとんど見られない。実習・ARを通じて学習者の学 びに注目しようとする姿勢が育成されつつあることが窺える。

・長い説明がなくてもぴったり合う状況でかつ学習者にとってもよく使うであろう自然 な文であるかどうか、その選択がうまくいけば学習者にスムーズに提示や練習がで き、それが学習者の貴重な時間を無䭾にしないことにつながる（実習生KS2002前）。

・最も基本で大切だと考えるのは、「まずは自分から」ということです。特に、全員 に聞こえる大きな声で話すこと、そして笑顔を忘れないことが大切だと思います（ 実習生NK2002前）。 
・ 一番好きなのは、先生が楽しくて内容も楽しい授業。次は先生が楽しくて内容はイ マイチな授業。そして、その次は先生がおもしろくない人で内容の楽しい授業。一 番イヤだったのはやっぱり、先生がおもしろくない人で内容もつまらない授業です （実習生TN2003前）。

一方、実習前の内省で「学習者をわかろうとする」ことが重要だとする理想 を示した実習生もあるが、しかし内容は非常に抽象的で漠然としている。

・学習者をわかろうとすること、そして人と人（教師と学習者、学習者と学習者）と のふれあいで教室活動は成り立っているのだということを忘れないことです（実習 生NM2003前）。

・（語学教師の） A 先生やY 先生の下で勉強していたころ、あんなにも楽 しく勉強できていたのは、先生方が私達のレベルに合わせて言葉や話す スピードを選んでいてくれたからなのだと実感している。…学習者ひと りひとりに合った指導\&つきあいができる先生になりたいと思っている （実習生HC2003前）。

これが、ARでテーマを考え、それを意識していくことで、各自のテーマが気 づかないうちに学習者への注目へと結びついていったことが実習後の報告に記 されている。

・学んだことは、「表情」という自分のテーマを持つことで、表情を中心とした、 授業の細かい点に前もって気を配れたこと、気を配ることの大切さに気づいた、 ということだと思います。‥いちいち小さいことに気を配ることで、学習者が見 えてくるように感じたからです。こんな絵カードを見せたら学習者はどんな反応 をするだろうかとか、こんな演技をして見せたらどんなふうに見えるのだろうか とか、気づかないうちに学習者のことを考えるようになっていたのです（実習生 NM2003後）。

・「教える」のではなく学習者の「学習のサポート」をするという言葉の意味をはじ めて理解できたように思う。…（ARのテーマである）分かりやすい指示を出す のも、適切な説明を行うのも、学習者の様子をよく把握できていなければできな い、というのがこの教育実習を通して得た一番大きい学びだったと思う（実習生 HC2003後）。

\section{ARのテーマにおける実習生の自己成長の認識}

一つのテーマに絞つて、授業見学・先行研究調査・実習授業を行うので、 そのテーマの中での自身の成長を認識できる。教育実習では学ぶべきことが多 く、その量に圧倒されてしまうと、実習中に何を学んだのかについての自己認 識ができなくなる場合がある。選択したテーマに一定期間集中し実施したARの 終了後、自身のプロセスを振り返ることで、自らの学びを実感できる。

・ ARは特に注意して見て欲しいところに焦点を絞って見てもらえるため、見学者からの コメントがとても参考になり、次のステップにすぐつなげることができる、というこ とを発見できて、ARというのは何もべテラン教師にのみ課せられることではなく、初 心者教師にも十分有効なものだということが分かった。そして、何か目的を一つ持つ て授業をするのとしないのとでは、全然違うことも知った（実習生AY2002後）。

・ その「テーマを探す」ということ自体が自分の授業についての振り返りに繋がり、 また自分が決めたテーマであるからこそ意識して改善し、意欲をもつて取り組め た。そして少しは成長することができたと思う（実習生HS2001後）。 
ARのテーマを選択すること自体、教育経験のない実習生の多くにとっては不 安と戸惑いを伴う作業である。実習生HS2002は、自身の教育哲学を記述するよ うに言われて困惑を感じ、次のように書いている。

・「私の日本語教育哲学」といっても、これまでそんなことは一度たりとも意識した ことのない私にとっては当初まったく見当がつきませんでした。そこでとりあえず

一番手っ取り早い方法として、これまでの言語学習の経験をさかのぼり、客観的に 考え直してみることにしました（実習生HS2002前）。

その後、ARでテーマを決めることによって焦点が定まり、実習生 HC2003は、漠然とした授業から具体的な授業の分析へと変わっていくことがで きた。

・ あらかじめ自分でテーマを決めて、それに注意しながら授業の回数を重ねていく ことは、ただ漠然と授業を行うよりはるかに有意義なことだと思います（実習生 HS2002後）。

また、実習生ON2002は、実習前の内省では自らの海外生活の経験から、発話 矯正の重要性を認識し、次のような強いビリーフで最後を締めくくっている。

・（海外生活の経験で）自分の話したいことをきちんと相手にわかる言葉で話すこと の重要性を痛感し、正しい発話に近づけるために、学習者の発話矯正は厳しくする 必要性があるのではないかと考えている（実習生ON2002前）。

しかし、実習後の報告では、自分の思い通りにならなかったことを反省し、 様々なことに気づいたことを記している。

・ARを通して私が学んだことは、適切な誤用訂正の難しさだ。私自身は、厳しい誤 用訂正をしようというビリーフを持っているにも関わらず、害際には考え通りには 行えていなかった事実に今回気づくことができた。最初は気づかなかった誤用訂正 時の自分の表情にも、ビデオで自分を客観的に見ることによって、気づくことがで きた（実習生ON2002後）。

「学習者同士のインターアクション」をARのテーマとした実習生HH2003の 実習前の内省には、以下のような漠然とした「学習者中心主義」の記述が見ら れた。

・「教師 $\rightarrow$ 学習者」という一方的なスタイルを無意識のうちに作り上げてしまってい ることに気づく。‥学習者としての立場を何らかの形で持ち続け、自らは黒子とな って学習者主体の授業を実践することが、私の現段階での日本語教育哲学であり、

目標である（実習生HH2003前）。

しかし、実習授業で指示がうまく伝わらず、苦労して用意した教材の中の材 料が学習者に全く用いられなかったという経験を通して、実習後の報告では、 教師主導の授業の中での学習者の主体的参加のありように対する具体的な考え が出てきている。

・ 日本の名所そのものが学習者にとって親しくないものであり、言葉も初めて耳に する固有名詞であったと考えられる。それなのに、各場所の紹介や言葉の口なら しの時間を学習者に与えなかったことで、結果的にこちらが与えた材料に大した 興味を持つこともないままに終わってしまった。…活動の目的を学習者に明確に 伝えることが必要となることを学び、それは今後の目標の一つとなった（実習生 HH2003後)。

まさに、この具体性を伴った気づきこそが、自己成長の種であると言えよ う。 


\section{ARの実習導入の意義と有効性}

前掲のMoreira, Vieira and Marques (1999)は、英語教育実習へのARの導入が 「学習者中心の教え方の重要性の認識」「教えることについての内省的態度の 助長」につながったという報告に加えて、ARを実施した教育実習生には、3つ の領域で変化が生じるとしている。

1. 信念と態度の変化（Belief and attitudal change） 言語学習と教育の目的、教師と学習者の役割、等についての信念や態度 を意識し表現することを通して、教えることをクリティカルに捉える力 が向上する。信念及び態度が、よりはっきりとした緻密なものになり、 外からコントロールされる学びから、自分自身でコントロールする学び へと変化していく。

2 . 概念の変化 (Conceptual change) 学習者にしっかりと焦点を合わせることによって、実習生には以下のよ うなことが生じる。
a. 教えることの有効性をはっきりと認識する
b. 教える/学ぶ際に優先すべきことについての理解が深まる
c. 教えることについて語る能力が向上し、実践上の理論を(再)構築する また、教えること/学ぶことを、探究的・発展的・自己統制的夕スクと して解釈する力が向上する。

3 . 手順の変化 (Procedural change)

実習生には、以下のような手順の変化が生じる。
a. よりシステマティックで組織化された行動
b. 決定する技術の向上
c. より創造的な計画
d. 学習者への焦点化

(Moreira、Vieira and Marques、1999)

これらは、岡崎・岡崎（1997:9-10）で述べている「自分なりに考えていく姿 勢を養い、それらを実践し、その結果を観察し改善していくような成長を作り 出す」に通じる結果とも言える。上記「1．信念と態度の変化」は、これまでで 述べた、(1)自己成長への積極的態度の養成につながるものであり、上記「2. 概念の変化」は、(4)学習者への注意力の養成につながるものであり、上記「 3. 手順の変化」は、(3)「研究者としての教師」の基礎の構築につながるもの である。通常の実習授業でも、ある程度の自己成長への積極的態度や、学習者 への注意力は養成されるが、ARの実施により、「教えることについての内省的 態度の助長」「学習者中心の教え方の重要性の認識」が、よりシステマティッ クに行われるようになると考えられる。

これらが(5)ARのテーマにおける実習生の自己成長の認識というかたちで 明確に示される点が、実習におけるAR導入の最大の特徵であろう。さらに、 (2)共同成長の実現を促すことができるのは、ARのデータをお互いに提供し合 
い、お互いの気づきを共有し合うためであり、教育実習でARを導入することに より、単独教師の個々のARでは見られない成果を生んでいると考えられる。

内省モデルによる教育実習の内省の特徵として、影山(2002)は「内省材料の 広範囲性」「内省の時間的広がり」「内省の変容性」の三つを挙げた。「内省 材料の広範囲性」「内省の時間的広がり」については、本研究でも同様の内省 が見られた。「内省の変容性」は、本研究で使用したデータでは特には見られ なかったが、各実習生のAR実践報告の中には、内省の深まりについての記述が 多い。例えば、

・（私のARのテーマである）「否定的フィードバック」に関する先行研究を読み、そ れについての議論を知ったが、実際にフィードバックをする際にどういうふうに 与えたらいか、私は真剣に考えたことがなかったような気がした。その時から、「 なぜ訂正しなかったのか」、また「なぜ訂正できなかったのか」について考えるよ うになった。まずは、自分の過去の学習経験から「人に認められたい。人に嫌われ たくない」という気持ちが強く働いているのではないかと思った。つまり、人に訂 正、又は指摘されることを非常に怖がっていたのだ。自分がそう思っているから、 人を批判できないし、するどく指摘できないのではないかと考えた。また、私はと ても緊張しがちなので、授業で緊張すると学習者の反応をしっかり受け止められな いこともその一因かも知れない（実習生CK2001後）。

このように、「ARを導入した実習」と「内省モデルによる実習」で、同傾向 の内省が見られたことは、興味深い。

\section{おわりに}

以上、ARを日本語教育実習に導入した場合の意義と有効性を考察してきた が、問題点もいくつかある。具体的には、(1)実習授業とARの二重負担 (2)学 習者からのデー夕収集の困難さ (3)担当授業とARテーマの不一致への対処 (4)テーマ選定による他への気づきの制限、などが挙げられる。

(1)の二重負担を感じる原因の一つとして、ARに対する理解不足が考えられ る。それを補うためには、実習期間を通じての「カンファレンス」すなわち教 師のオフィスに学習者が一人又はグループでやってきて、自身の学習成果につ いてのフィードバックを教師からもらう方法（Brown、1998）の実施が考えら れる。また、(2)については、実習機関へのARに対する理解と協力を依頼するこ とで、(3)や(4)についてはテーマの選定や授業担当の日程調整や担当教官の問い かけなど、実習担当者の配慮によって解決できる可能性が考えられる。

ARの場合、話を聞いただけでは十分な（すなわちAR実施に速やかに取り掛 かれる程度の）理解を得ることは困難で、実際に体験してみなければ本当の理 解に繋がらないことが多い。したがって(1)のカンファレンスの実施は実習期間 を通じてでなければ行えないが、担当教官の時間上の制約もあり、すべての学 生に対するフィードバックにかける時間を更に増やすという方法は、現実的で はない。

そこで、特に教育経験のない実習生に対するAR自体の負担の軽減を目的と して、2003年度は、Allwright（1993、1999）による「探究的授業(Exploratory Teaching)」を援用して実習カリキュラムに取り入れ、ARか探究的授業いずれ か実施可能なものを実習生自身に選択させた。具体的には、多くの授業ビデオ の視聴およびその観察記録の提出だけでなく、前年度までの教育実習における AR 実践報告を熟読し、AR実施者のテーマ選定理由、データ収集方法、実施者 
の「学び」等についてまとめたレポートを提出させ、実践研究についてのイメ ージを高めさせる課題を課した。

探究的授業の実施により、2003年度の実習生の報告書からは、前年度まで見 られた、

・ARのテーマを決めなければいけなくなった。しかし、全く授業をした経験がなか つたため自分の授業がどういうものなのか、どこに注目すればよいのか全く分から ず困ってしまった（実習生KA2001後）。

等に類する意見が見られなくなった。探究的授業は日本語教育の現場で生じ ていることに対する「理解の深まり」を主な目標としている。「問題解決型」 であるARに対し、探究的授業は「問題発見型」の実践研究であると言えよう。

本研究はあくまで事例研究であり、その結果および考察も、本研究の枠内で 捉えられるべき性質のものである。異なる形式でARを日本語教育実習に導入し た場合には、本研究とは異なる結果が出てくることも当然予想される。教師成 長型の教育実習の可能性と問題点の究明には、更なる事例研究の積み重齐が必 要である。これからも、得られた問題点を改善点としてさらに研究を進めたい と考える。

註：1 同実習の実習生自身によるARの実践報告に、福島・福田（2000）が ある。

2 データの客観性を高めるために、データ収集に 2 人以上の人間を使う こと(Freeman、1988)。

横溝紳一郎（YOKOMIZO， Shinichiro）は1997年5月にハワイ大学大学院マノ ア校より博士号（Ph.D.）を取得（日本語学）。広島大学大学院教育学研究科助 教授。専門は教師成長の方法論。

迫田久美子（SAKODA，Kumiko）は1996年広島大学大学院より博士号を取得 (教育学) 。広島大学大学院教育学研究科教授。専門は日本語教育学、第二言 語習得論。

松崎寛（MATSUZAKI，Hiroshi）は1991年筑波大学大学院より国際学修士号を 取得。広島大学大学院教育学研究科講師。専門は日本語教育方法論、音声教育。

\section{参考文献}

小笠恵美子・楊晶・郭末任・金考卿・池田玲子 (2000)「実習授業における教師 の成長をめざす教授活動評価のあり方」『日本語教育学会春季大会予稿集』 160-165.

岡崎敏雄・岡崎眸（1997）『日本語教育の実習 : 理論と実践』アルク

岡崎眸編著 (2002a) 『多言語・多文化社会を切り開く日本語教員養成日本語教育 実習を振り返る（内省モデルに基づく日本語教育実習理論の構築 : 実習報告 編）』平成11-13年度科学研究費補助金研究基盤研究(C) (2)研究成果報告書 岡崎眸編著（2002b）『内省モデルに基づく日本語教育実習理論の構築』平成1113年度科学研究費補助金研究基盤研究(C) (2)研究成果報告書 
小熊利江・スニーラット =ニャンジャローンスック (2000)「大学院での日本語教 育実習がもたらす教育観の変化 : 日本語教師と日本語の授業に対するイメー ジを中心に」『日本語教育学会春季大会予稿集』166-171.

尾崎明人 - 西原鈴子 - 加藤清方 - 長友和彦 - 磯村美保子 - 岡眞理子 - 足立祐子 (2000)「日本語教師養成のあり方と課題」『日本語教育学会秋季大会予稿 集』19-45.

影山陽子（2002）「内省モデルに基づく教育実習における内省」岡崎眩編著『内 省モデルに基づく日本語教育実習理論の構築』平成11-13年度科学研究費補 助金研究基盤研究 (C) (2)研究成果報告書、287-297.

迫田久美子（2000）「アクション・リサーチを取りいれた教育実習の試み：自己 研修型の教師を目指して」『広島大学日本語教育学科紀要』第10号、21-30. 白石知代・松田文子・池田広子・香山理恵（2000）「教育実習生は学習者のやり 取りを通した柔軟な意思決定ができるか」『日本語教育学会春季大会予稿 集』148-153.

津田彰子（1998）「教師の指名と学習者の反応に関するアクション・リサーチ」 『ティーチング・ポートフォリオ : 現職教師の自己成長の記録』南山大学外 国人留学生別科、30-39.

中村透子・山田真理（2000）「作文指導における文法授業：『に』『で』を中心 に」『月刊日本語』1月号、58-61.

日本語教員養成課程研究委員会 (2001) 『大学日本語教員養成課程において必要 とされる新たな教育内容と方法に関する調査研究報告書』日本語教員養成課 程研究委員会

林さと子・八田直美 (2000)「接触体験を重視した日本語教育実習 : ネットワー ク型実習へ」『日本語教育学会春季大会予稿集』154-159.

福島妙子・福田倫子（2000）「教師の不自然なティーチャートーク：文末の上昇 イントネーション」『月刊日本語』2月号、62-65.

堀口純子(1992)「日本語教育実習指導のための基礎的研究」『日本語教育』 78号、154-166.

三原祥子・矢部まゆみ・影山陽子・澤田尚美 (2001)「対話を通した文章表現の プロセスについてのアクション・リサーチ：『ほぐす』『ほりおこす』『つ たえる』『わかちあう』文章表現のプロセス」『日本語教育学会秋季大会予 稿集』213-214.

横井和子(1999)「発音チェックとフィードバック」『月刊日本語』12月号、5861.

横溝紳一郎 (2000a)『日本語教師のためのアクション・リサーチ』日本語教育学 会編、凡人社

横溝紳一郎 (2000b)「ポートフォリオ・ビデオ評価に関するアクション・リサー チ」『JALT日本語教育論集』第5号、12-23.

横溝紳一郎・迫田久美子・松崎寛（2002）「日本語教育実習でのアクション・

リサーチの役割」『日本語教育学会秋季大会 予稿集』178-183.

横溝紳一郎・當作靖彦（2003）「アメリカの教育改革から日本国内の日本語教師 教育への提言」當作靖彦編『日本語教師の専門能力開発: アメリカの現状と 日本への提言』日本語教育学会、167-205. 
Allwright, D. (1993). Integrating research and pedagogy: Appropriate criteria and practical possibilities. In J. Edge \& K. Richards (Eds.), Teachers develop teachers research: Papers on classroom research and teacher development (pp. 125-135). Oxford: Heinemann.

Allwright, D. (1999). Exploratory practice in the language classroom. Paper presented at the JALT conference, Maebashi, Japan.

Brown, J. D. (1998). Editor's note. In J. D. Brown (Ed.), New ways of classroom assessment (pp. 3-5). Alexandria, VA: TESOL.

Freeman, D. (1998). Doing teacher-research: From inquiry to understanding. New York: Heinle and Heinle Publishers.

Johnson, K. (1993). What I planned-What I did: Reflecting on planning and teaching during the practicum. In D. Freeman \& S. Cornwell (Eds.), New ways in teacher education (pp. 75-79). Alexandria, VA: TESOL.

Markee, N. (1996). Making second classroom research work. In J. Schachter \& S. Gass (Eds.), Second language classroom research: Issues and opportunities (pp. 117-155). Mahwah, NJ: Lawarence Erlbaum Associates.

Moreira, M. A., Vieira, F., \& Marques, I. (1999). Pre-service teacher development through action research. The Language Teacher, 23(12), 15-18.

Nunan, D., \& Lamb, C. (1996). The self-directed teacher: Managing the learning process. New York: Cambridge University Press.

Rossiter, A. (1993). Teacher educators and classroom research: Practising what we preach. In J. Edge and K. Richards (Eds.), Teachers develop teachers research: Papers on classroom research and teacher development (pp. 136146). Oxford: Heinemann.

Schön, D.A.(1983). The reflective practitioner: How professionals think in action. London: Temple Smith.

Stephens, D. \& Reimer, K. M. (1993). Explorations in reflective practice. In L. Patterson, C. M. Santa, K. Short, \& K. Smith (Eds.), Teachers are researchers: Reflection and action (pp. 160-172). Newmark, DE: International Reading Association.

Thorne, C., \& Qiang, W. (1996). Action research in language teacher education. ELT Journal, 50(3), 254-262.

Wallace, M. (1991). Training foreign language teachers: A reflective approach. New York: Cambridge University Press.

(Received May 21, 2003; revised August 25, 2004) 